\title{
ANALISIS KANDUNGAN LOGAM BERAT KADMIUM (Cd) \\ PADA IKAN BANDENG (Channos channos) DI PERTAMBAKAN KECAMATAN PANGKAJENE
}

\author{
Haeriah* \\ *Jurusan Biologi Fakultas Sains dan Teknologi \\ Universitas Islam Negeri (UIN) Alauddin Makassar \\ email: Haeriah@yahoo.com
}

\begin{abstract}
This research is done to know the values of precious metal cadmium $(\mathrm{Cd})$ contained in milk fish (Channos channos) at Pangkajene subdistrict earthen dam. The sample analize in done by SSA. The result is gotten to show the values of precious metal cadmium $(\mathrm{Cd})$ in kidney as much as 0,1070 ppm, heart 0,1002 $\mathrm{ppm}$, intestines $0,0665 \mathrm{ppm}$ and muscle $0,0361 \mathrm{ppm}$. The values of precious metal cadmium that get from all the sample of milk fish (Channos channos) at Pangkajene subdistrict earthen dam according WHO that still below of standardization cadmium concentration at fish namply $0,2 \mathrm{ppm}$.
\end{abstract}

Keywords: Cadmium, Milk fish, Channos channos

\section{PENDAHULUAN}

$\mathbf{I}$

kan Bandeng dikenal juga sebagai ikan Bolu, merupakan jenis ikan air tawar (biasanya di tambak) yang sangat populer di Asia Tenggara, terkhusus di Sulawesi Selatan. Ikan bandeng (Channos channos)

merupakan salah satu spesies yang banyak dibudidayakan oleh masyarakat dan termasuk dalam familia chanidae. Bentuk tubuh ikan bandeng panjang dan ramping menyerupai torpedo. Dalam waktu kurang lebih enam bulan dalam kondisi normal, mampu berkembang hingga mencapai panjang antara 30-60 cm (Prahasta dan Masturi, 2008).

Ikan Bandeng merupakan komoditas perikanan yang memiliki peluang usaha cukup baik khususnya di kecamatan Pangkajene kabupaten Pangkep karena 
sangat digemari oleh masyarakat. Hal ini disebabkan karena rasa ikan bandeng yang enak dan gurih serta kandungan gizinya sangat tinggi. Komposisi gizi ikan bandeng per $100 \mathrm{~g}$ adalah energi $129 \mathrm{kkal}$, protein $20 \mathrm{~g}$, lemak 4,8 g, kalsium 20 $\mathrm{mg}$, fosfor $150 \mathrm{mg}$, besi $2 \mathrm{mg}$, vitamin A $150 \mathrm{SI}$, dan vitamin B1 0,05 mg (Kandungan Gizi Bandeng, 2009).

Untuk meningkatkan produksi ikan bandeng, maka dilakukan pembudidayaan di tambak-tambak. Namun usaha pertambakan ini kemungkinan tercemari oleh limbah industri yang terdapat di daerah tersebut. Limbah buangan industri seperti industri semen dan industri pembuat kantong semen diduga mengalir ke perairan umum dan masuk ke dalam lingkungan perairan dan areal pertambakan. Limbah industri tersebut kemungkinan mengandung unsur logam berat yang cepat atau lambat dapat mengakibatkan kerusakan ekosistem perairan tambak. Selain limbah industri, peningkatan pencemaran logam berat di areal pertambakan juga dapat di sebabkan oleh limbah industri rumah tangga seperti sisa-sisa deterjen, sampah-sampah metabolik, kondisi pipa-pipa air dan produkproduk konsumen lainnya yang dibuang masuk ke perairan.

Nursanti (2004) mengemukakan bahwa penyebab terjadinya pencemaran logam berat pada sebuah perairan biasanya berasal dari masukan air yang terkontaminasi oleh buangan limbah industri dan pertambangan. Limbah industri dan limbah rumah tangga dapat masuk ke dalam laut melalui sungai-sungai dan saluran-saluran pembuangan. Limbah industri dan limbah rumah tangga pada mulanya akan diencerkan dan kekuatan pencemarannya secara perlahan-lahan akan diperlemah sehingga menjadi tidak berbahaya, namum bila buangan tersebut semakin banyak dan melampaui daya dukung lingkungan, maka bahan buangan tersebut secara perlahan-lahan akan menumpuk menyebabkan pencemaran yang serius terhadap lingkungan laut misalnya air laut itu sendiri atau sedimen laut.

Salah satu logam berat yang kemungkinan ikut terbawa dari laut ke pertambakan adalah logam berat kadmium. Logam ini sangat berbahaya karena oksida yang dihasilkan dari logam berat kadmium adalah logam yang toksisitasnya tinggi. Sebagian besar kontaminasi oleh logam kadmium pada manusia melalui makanan dan rokok. Proporsi yang besar adalah melalui 
pernapasan yaitu antara $10-40 \%$ tergantung keadaan fisik. Wilayah uap kadmium sangat toksis dengan lethal dose melalui pernafasan diperkirakan 10 menit terpapar sampai dengan $190 \mathrm{mg} / \mathrm{m}^{3}$ atau sekitar $8 \mathrm{mg} / \mathrm{m}^{3}$ selama 240 menit akan dapat menimbulkan kematian (Dampak Terhadap Manusia Akibat Tercemar Oleh Logam Berat Cadmium (Cd), 2009).

Toksisitas kronis $\mathrm{Cd}$, baik melalui inhalasi maupun oral, bisa menyebabkan kerusakan tubulus renalis, kerusakan ginjal yang ditunjukkan oleh ekskresi yang berlebihan, protein berat molekul rendah, gangguan ginjal, gangguan sistem kardiovaskuler, gangguan sistem skeletal, menurunkan fungsi pulmo, empisema, kehilangan mineral tulang yang disebabkan oleh disfungsi nefron ginjal, berkurangnya reabsorbsi $\mathrm{Ca}$, dan terjadinya peningkatan ekskresi $\mathrm{Ca}$ yang berpengaruh terhadap tulang. Peningkatan ekskresi $\mathrm{Ca}$ tersebut diantaranya menyebabkan osteoporosis dan osteamalsia, anemia, diskolorasi gigi menjadi kuning, rhinitis, ulserasi septum nasal, anosmia, proteinuria, azotemia, jaundice, terjadinya kanker paru-paru dan prostat (Widowati dkk., 2008).

Berdasarkan uraian di atas, maka penelitian tentang kandungan logam berat kadmium (Cd) pada ikan bandeng (Channos channos) yang diperoleh dari beberapa daerah pertambakan di Kecamatan Pangkajene kabupaten Pangkep dipandang perlu untuk dilakukan.

\section{Tujuan Penelitian}

Untuk mengetahui kadar kandungan logam berat kadmium (Cd) pada ikan bandeng (Channos channos) di pertambakan di kecamatan Pangkajene.

\section{METODE PENELITIAN}

\section{Sampel Air Laut dan Sungai}

Sampel air laut dan air sungai diambil sebanyak $50 \mathrm{ml}$, kemudian dimasukkan kedalam gelas ukur. Setelah itu di tambahkan $\mathrm{HNO}_{3}$ pekat sebanyak $5 \mathrm{ml}$ dan $\mathrm{H}_{2} \mathrm{SO}_{4}$ pekat sebanyak 2,5 ml, lalu di dekstruksi di ruang asam hingga volume sampel menjadi $15 \mathrm{ml}$. Sampel kemudian didinginkan kemudian 
ditambahkan aquadest sebanyak $50 \mathrm{ml}$. Sampel disaring menggunakan kertas whatman -42 , hasil filtrat di masukkan kedalam botol kaca.

\section{Sampel Sedimen Laut dan Sungai}

Sampel sedimen laut dan sedimen sungai diambil sebanyak $10 \mathrm{mg}$, kemudian di masukkan kedalam gelas kimia. Setelah itu, di tambahkan $\mathrm{HNO}_{3}$ pekat sebanyak $10 \mathrm{ml}$ kemudian di dekstruksi di atas hot plate. Setelah sampel dingin kemudian di tambahkan aquadest sebanyak $50 \mathrm{ml}$ lalu di saring menggunakan kertas whatman-42. Hasil filtrat kemudian di masukkan kedalam botol.

\section{Sampel Ikan Bandeng}

Daerah yang menjadi lokasi pengambilan sampel yaitu daerah pertambakan di kelurahan Anrong Appaka dan kelurahan Sibatua kecamatan Pangkajene. Pelaksanaan penelitian terdiri dari tiga tahap, yaitu:

\section{Pengambilan sampel}

Pengambilan sampel dilakukan dengan cara mengambil beberapa sampel ikan bandeng (Channos channos) di daerah pertambakan di kelurahan 1 dan kelurahan 2 kecamatan Pangkajene, yang meliputi 3 titik pengambilan sampel di daerah pertambakan. Setiap lokasi pengambilan sampel ikan bandeng (diambil 10 ekor ikan bandeng yang berumur 6 bulan kemudian dikomposit, selanjutnya diberi tanda untuk membedakan dengan sampel ikan bandeng yang di ambil dari lokasi yang berbeda.

\section{Penyiapan sampel}

Sampel yang di ambil terlebih dahulu di bersihkan dari kotoran yang melekat, lalu di bilas dengan aquadest. Setelah bersih, sampel tersebut di potong untuk memisahkan organ hati, ginjal, usus dan otot. Selanjutnya, masing-masing organ sampel di masukkan kedalam cawan petri yang telah di beri label. Sampel kemudian di timbang menggunakan neraca analitik sebanyak 10 gr lalu di masukkan ke dalam cawan porselin. Sampel yang ada di dalam cawan porselin kemudian di masukkan ke dalam furnace tipe 
1400 dan tipe 48000 untuk di abukan selama 2 jam. Setelah itu, sampel di dinginkan lalu di tambahkan $\mathrm{HNO}_{3}$ pekat kemudian di dekstruksi di atas hot plate selama 1 jam. Sampel yang telah di dekstruksi kemudian di dinginkan, lalu di tambahkan $50 \mathrm{ml}$ aquedest. Sampel di saring menggunakan kertas Whatman-42 dan hasil filtrat di tampung dalam botol kaca.

\section{Pengujian Sampel}

\section{a. Pembuatan larutan standar}

Sebelum sampel di analisis, terlebih dahulu di buat larutan standar kadmium 100 ppm. Larutan baku kemudian di pipet masingmasing 2, 4, 6, 8 dan $10 \mathrm{ml}$ kemudian masing-masing di tambah dengan $50 \mathrm{ml}$ aquadest untuk pembuatan larutan standar 1, 2, 3, 4, dan 5 ppm.

\section{b. Penentuan kadar kadmium dalam sampel}

Sampel yang telah di dekstruksi dan larutan standar kemudian dianalisis dengan spekrofotometer serapan atom (SSA) tipe AA 6200 dengan panjang gelombang $229,1 \mathrm{~nm}$.

\section{HASIL DAN PEMBAHASAN}

\section{A. Hasil Penelitian}

Analisis kandungan logam berat kadmium (Cd) dilakukan pada sampel air (laut dan sungai), sampel sedimen (laut dan sungai), dan sampel organ ikan bandeng (ginjal, hati, usus, dan otot) yang diambil dari pertambakan kecamatan Pangkajene.

\section{Sampel Air Laut dan Sungai}

Pengujian kandungan logam berat kadmium (Cd) pada sampel air laut dan air sungai ditampilkan pada tabel 1 .

Tabel 1. Kadar Kandungan Logam Berat Kadmium (Cd) pada Sampel Air Laut dan Air Sungai

\begin{tabular}{|c|c|c|}
\hline No. & Kode sampel & Kadar Cd (ppm) \\
\hline 1. & AL & 0,0015 \\
\hline 2. & AS & 0,0012 \\
\hline
\end{tabular}


Keterangan :

AL : Air Laut

AS : Air Sungai

\section{Sampel Sedimen Laut dan Sungai}

Pengujian kadar kandungan logam berat kadmium (Cd) pada sampel sedimen laut dan sedimen sungai ditampilkan pada tabel 2.

Tabel 2. Kadar Kandungan Logam Berat Kadmium (Cd) pada Sampel Sedimen Laut dan Sedimen Sungai

\begin{tabular}{|c|c|c|}
\hline No. & Kode sampel & Kadar Cd (ppm) \\
\hline 1. & SL & 0,2015 \\
\hline 2. & SS & 0,0670 \\
\hline
\end{tabular}

Keterangan :

SL : Sedimen Laut

SS : Sedimen Sungai

\section{Sampel Ikan Bandeng (Channos channos)}

Pengujian kadar kandungan logam berat kadmium $(\mathrm{Cd})$ pada sampel organ ikan bandeng pada kelurahan 1 ditampilkan pada tabel 3 .

Tabel 3. Kadar Kandungan Logam Berat Kadmium (Cd) pada Sampel Organ Ikan Bandeng pada Kelurahan 1

\begin{tabular}{|c|l|c|c|c|c|}
\hline No. & \multicolumn{1}{|c|}{ Organ } & A1 & B1 & C1 & $\begin{array}{c}\text { Rata-rata } \\
\text { Kadar Cd } \\
\text { (ppm) }\end{array}$ \\
\hline 1 & Ginjal & 0,0829 & 0,1202 & 0,0992 & 0,1008 \\
\hline 2 & Hati & 0,1211 & 0,1191 & 0,0330 & 0,0911 \\
\hline 3 & Usus & 0,0763 & 0,0533 & 0,0524 & 0,0607 \\
\hline 4 & Otot & 0,0542 & 0,0361 & 0,0464 & 0,0456 \\
\hline
\end{tabular}

Keterangan:

A1 : Lokasi dekat jalan raya kelurahan 1

B1 : Lokasi dekat sungai kelurahan 1

C1 : Lokasi dekat pemukiman kelurahan 1

Pengujian kadar kandungan logam berat kadmium (Cd) pada sampel organ ikan bandeng pada kelurahan 2 ditampilkan pada tabel 4 . 
Tabel 4. Kadar Kandungan Logam Berat Kadmium (Cd) pada Sampel Organ Ikan Bandeng pada Kelurahan 2

\begin{tabular}{|c|l|c|c|c|c|}
\hline No. & Organ & A2 & B2 & C2 & $\begin{array}{c}\text { Rata-rata } \\
\text { Kadar Cd } \\
\text { (ppm) }\end{array}$ \\
\hline 1 & Ginjal & 0,1393 & 0,0991 & 0,1018 & 0,1134 \\
\hline 2 & Hati & 0,1093 & 0,1137 & 0,1051 & 0,1094 \\
\hline 3 & Usus & 0,0714 & 0,0823 & 0,0634 & 0,0724 \\
\hline 4 & Otot & 0,0399 & 0,0537 & 0,0401 & 0,0446 \\
\hline
\end{tabular}

Keterangan:

A2 : Lokasi dekat jalan raya kelurahan 2

B2 : Lokasi dekat sungai kelurahan 2

C2 : Lokasi dekat pemukiman kelurahan 2

Rata-rata kadar kandungan logam berat kadmium (Cd) pada sampel organ ikan bandeng di kedua kelurahan di kecamatan Pangkajene ditampilkan pada tabel berikut ini.

Tabel 5. Rata-rata Kadar Kandungan Logam Berat Kadmium (Cd) pada Sampel Organ Ikan Bandeng di kecamatan Pangkajene

\begin{tabular}{|c|l|c|c|c|}
\hline No. & Organ & Kelurahan 1 & Kelurahan 2 & $\begin{array}{c}\text { Rata-rata } \\
\text { Kadar Cd } \\
(\mathrm{ppm})\end{array}$ \\
\hline 1 & Ginjal & 0,1008 & 0,1134 & 0,1071 \\
\hline 2 & Hati & 0,0911 & 0,1094 & 0,1003 \\
\hline 3 & Usus & 0,0607 & 0,0724 & 0,0665 \\
\hline 4 & Otot & 0,0456 & 0,0446 & 0,0451 \\
\hline
\end{tabular}

\section{B. Pembahasan}

Logam berat merupakan komponen alami tanah. Elemen ini tidak dapat didegradasi maupun dihancurkan (Martaningtyas, 2007). Logam berat sendiri sebenarnya merupakan unsur esensial yang sangat di butuhkan setiap makhluk hidup, namun beberapa diantaranya (dalam kadar tertentu) bersifat toksik. Di alam, unsur ini biasanya terdapat dalam bentuk terlarut atau tersuspensi (terikat dengan zat padat) serta terdapat sebagai bentuk ionic (Mursyidin, 2006).

Salah satu jenis logam berat yang dapat menyebabkan pencemaran lingkungan adalah logam kadmium dan macam- macam persenyawaannya, yang dapat masuk ke lingkungan terutama sebagai efek samping dari aktifitas manusia. 
Kadmium merupakan salah satu logam non esensial yang dapat menyebabkan keracunan akut dan kronis karena sifat dari logam berat yaitu dapat terakumulasi dalam tubuh. Selain diduga karsinogenik, logam Kadmium (Cd) dapat menyebabkan gangguan pada pencernaan, ginjal dan kerusakan tulang (Palar, 2008). Selain itu, logam berat Kadmium juga dapat menghambat perkembangan otak dan kanker pada anak (Wibowo, 2010).

\section{Sampel Air Laut dan sungai}

Daerah pengambilan sampel air laut (AL) merupakan daerah pesisir pantai yang berdekatan dengan lokasi pengambilan sampel ikan bandeng. Dari hasil penelitian, kandungan logam kadmium pada air laut senilai 0,0015 ppm menurut BPLDH termasuk kedalam kategori kelas B (tercemar ringan) >0,00011 - 0,01 ppm (Lestari dan Edward, 2004). Sedangkan hasil penelitian pada sampel air sungai (AS) di peroleh sebanyak 0,0012 ppm. Daerah pengambilan sampel AS ini merupakan sungai yang berdekatan dengan lokasi pengambilan sampel. Sungai di daerah ini bersambungan langsung dengan laut yang ada di sekitar lokasi pengambilan sampel. Dari hasil penelitian, kandungan logam kadmium pada air sungai masih dibawah standar yang di tentukan oleh Menteri Kesehatan RI nomor : 173/ MenKes/ Per/ VIII/ 1977, tentang pengawasan pencemaran air dan badan air untuk berbagai kegunaan yang berhubungan dengan kesehatan dan Peraturan Pemerintah Republik Indonesia Nomor 82 Tahun 2001 tentang pengolahan kulaitas air dan pengendalian pencemaran air, disebutkan bahwa kadar kadmium maksimun untuk badan air yang peruntukannya digunakan sebagai pertanian dan perikanan sebesar 0,01 ppm (Sutrisno dan Budiyono, 2004).

\section{Sampel Sedimen Laut dan sungai}

Pengambilan sampel sedimen laut (SL) dilakukan di tempat yang sama dengan pengambilan sampel air laut yaitu daerah pesisir pantai yang berdekatan dengan lokasi pengambilan sampel ikan bandeng dan mengandung kadmium senilai 0,2015 ppm. Demikian pula pengambilan sampel sedimen sungai (SS) dilakukan di tempat yang sama dengan lokasi pengambilan sampel air dan 
mengandung kadmium senilai 0,0370 ppm. Hasil penelitian yang diperoleh menunjukkan bahwa kadar sedimen laut dan sungai masih di bawah standar menurut Reseau National d' Observation dan Afrisal tahun 2000 yaitu 0,1-2 ppm (Ahmad, 2009).

Tingginya kadar logam kadmium pada sedimen jika dibandingkan dengan kadar logam kadmium di air, disebabkan karena dalam lingkungan perairan logam berbentuk berupa ion-ion bebas, pasangan ion organik dan ion kompleks. Kelarutan logam dalam air akan di kontrol oleh pH air. Kenaikan pH menurunkan kelarutan logam dalam air, karena kenaikan $\mathrm{pH}$ mengubah kestabilan dari bentuk karbonat menjadi hidroksida yang membentuk ikatan dengan partikel dengan badan air, sehingga akan mengendap membentuk lumpur. Logam berat yang terlarut dalam air akan berpindah ke dalam sedimen jika berikatan dengan materi organik bebas atau materi organik yang melapisi permukaan sedimen dan penyerapan langsung oleh permukaan partikel sedimen. Materi organik dalam sedimen dan kapasitas penyerapan logam sangat berhubungan dengan ukuran partikel dan luas permukaan penyerapan sehingga konsentrasi logam dalam sedimen biasanya di pengaruhi ukuran partikel dalam sedimen (Rini, 1999).

\section{Sampel Ikan Bandeng}

\section{Ginjal}

Berdasarkan hasil penelitian, diketahui bahwa kadar logam berat kadmium yang tertinggi pada organ ginjal ikan bandeng terdapat pada sampel GA2 (ikan bandeng yang diambil dekat Jalan raya kelurahan 2) sebanyak 0,1393 ppm, sedangkan kadar terendah kandungan logam berat kadmium terdapat pada sampel GA1 (ikan bandeng yang diambil dekat Jalan raya kelurahan 1) sebanyak 0,0829 ppm. Dari hasil penelitian dapat di ketahui bahwa kadar kadmium yang terdapat pada ginjal ikan bandeng (Channos channos) masih di bawah standar yang di tentukan oleh Badan Kesehatan Dunia (WHO) yaitu 0,2 ppm (Widowati dkk., 2008). Tingginya kadar kandungan logam Kadmium pada organ ginjal ikan, disebabkan karena ginjal merupakan tempat akumulasi logam berat kadmium. 


\section{Hati}

Berdasarkan hasil penelitian, diketahui bahwa kadar logam berat kadmium tertinggi pada organ hati ikan bandeng (Channos channos) terdapat pada sampel HA1 (ikan bandeng yang diambil dekat jalan raya kelurahan 1) sebanyak 0,1211 ppm, sedangkan kadar logam berat kadmium terendah terdapat pada sampel HC1 (ikan bandeng yang diambil dekat pemukiman kelurahan 1) sebanyak 0,0330 ppm. Rendahnya kadar logam berat pada hati ikan bandeng yang berdekatan dengan pemukiman kelurahan 1dibandingkan dengan tempat pengambilan lokasi sampel lainnya, karena dilihat dari jumlah penduduk yang mendiami kelurahan tempat pengambilan sampel ikan bandeng jumlahnya lebih sedikit jika dibandingkan dengan tempat pemukiman yang ada di kelurahan 2.

Dari data tersebut diatas, diketahui bahwa kadar kadmium pada hati ikan menurut WHO masih aman untuk di komsumsi karena kadar logam kadmium pada organ hati ikan masih dibawah ambang batas yaitu 0,2 ppm (Widowati dkk., 2008). Hati merupakan organ yang sangat penting pada hewan, karena hati merupakan organ detoksikasi dan banyak memproduksi enzim metabolisme (Darmono, 2001). Oleh karena itu, kadar logam berat kadmium (Cd) pada hati ikan bandeng juga tinggi karena fungsi hati sebagai detoksikasi dalam tubuh.

\section{Usus}

Berdasarkan hasil penelitian diketahui bahwa kadar logam berat kadmium yang tertinggi pada usus ikan bandeng (Channos channos) terdapat pada sampel UB2 (ikan bandeng yang diambil dekat sungai kelurahan 2) sebanyak 0,0823 ppm, sedangkan kadar logam berat kadmium terendah terdapat pada sampel UC1 (ikan bandeng yang diambil dekat pemukiman kelurahan 1) sebanyak 0,0524 ppm. Berdasarkan data di atas, dapat diketahui bahwa kadar logam berat kadmium pada usus ikan bandeng (Channos channos) masih aman dikomsumsi karena kadar logam kadmium pada usus ikan bandeng masih berada dibawah ambang batas yang ditentukan oleh WHO yaitu 0,2 ppm (Darmono, 2001). 


\section{Otot}

Berdasarkan hasil penelitian diketahui bahwa kadar logam berat kadmium yang tertinggi terdapat pada sampel OA1 (ikan bandeng yang diambil dekat jalan raya kelurahan 1) sebanyak 0,0542 ppm, sedangkan kadar logam berat terendah terdapat pada sampel OB1 (ikan bandeng yang diambil dekat sungai kelurahan 1) sebanyak 0,0361 ppm. Dari data diatas, diketahui kadar logam kadmium pada otot ikan bandeng dikelurahan 1 dan kelurahan 2 masih aman untuk dikomsumsi karena masih dibawah standar yang ditentukan oleh WHO yaitu 0,2 ppm (Darmono, 2001).

Hasil penelitian memperlihatkan bahwa organ ginjal merupakan tempat akumulasi logam kadmium yang paling tinggi nilai kadarnya yaitu 0,1070 ppm, kemudian organ hati dengan kadar kadmium sebanyak 0,1003 ppm, organ usus dengan kadar kadmium sebanyak 0,0665 ppm, dan otot dengan kadar kadmium sebanyak 0,0451 ppm. Berdasarkan dari data tersebut diatas, maka dapat diketahui bahwa ginjal dan hati merupakan tempat akumulasi logam kadmium tertinggi di dalam tubuh makhluk hidup. Hal ini disebabkan karena ginjal merupakan organ utama dari sistem urinaria hewan tingkat tinggi. Pada organ ini terjadi proses pemisahan akhir (filtrasi) dari hasil-hasil metabolisme yang dibawa oleh darah. Dalam proses kerja dan fungsinya, ginjal akan melanjutkan bahanbahan yang masih di butuhkan oleh tubuh untuk dibawa kembali oleh darah, sedangkan bahan-bahan yang tidak lagi dibutuhkan oleh tubuh akan dibuang bersama urine (air seni). Namun demikian, pada organ ini juga terjadi peristiwa akumulasi dari bermacam-macam bahan termasuk logam kadmium (Cd) (Palar, 2008). Sedangkan hati merupakan organ detoksikasi (penetralisisr racun) dalam tubuh.

Logam berat dapat masuk kedalam tubuh ikan melalui tiga jalan yaitu: saluran pernafasan, saluran pencernaan, dan penetrasi melalui kulit. Logam yang masuk kedalam tubuh ikan, kemudian diabsorbsi dan diangkut oleh darah, darah kemudian berikatan dengan protein darah yang kemudian didistribusikan ke seluruh jaringan tubuh. Akumulasi logam yang tertinggi biasanya dalam detoksikasi (hati) dan ekskresi (ginjal). Akumulasi logam berat dalam tubuh 
organisme ikan tergantung pada konsentrasi logam berat dalam air, lingkungan, suhu, keadaan spesies dan aktifitas fisiologi (Connel dan Miller, 2006).

Keberadaan logam kadmium pada ikan bandeng sebagaimana fakta dalam penelitian ini, diduga karena ikan bandeng bersifat detrivorus (pemakan sisa-sisa) dan bergerak serta mencari makanannya di dasar air, sedangkan zona tersebut merupakan tempat endapan dari berbagai jenis limbah termasuk logam kadmium, maka ikan bandeng merupakan salah satu organisme yang sangat berpotensi menyerap logam kadmium.

Proses bioakumulasi logam dalam jaringan ikan cukup bervariasi, tergantung pada jenis logam dan spesies ikan. Beberapa jenis logam terakumulasi lewat rantai makanan. Di antara jenis logam berat ternyata kadmium merupakan logam yang penetrasinya dan akumulasinya dalam jaringan tidak terpengaruh terhadap hadirnya logam lain. Kadmium merupakan logam yang berpotensi tertimbun dalam jaringan hewan air seperti ikan bandeng selain merkuri (Darmono, 2001) sehingga manusia sebagai konsumen ikan bandeng hendaknya mengupayakan sedemikian rupa upaya-upaya yang dapat mengurangi tingkat pencemaran lingkungan untuk menekan akumulasi cemaran logam berat pada semua sumber pangan yang dikonsumsi.

\section{PENUTUP}

\section{Kesimpulan}

Berdasarkan hasil yang diperoleh pada penelitian analisis kandungan logam berat kadmium (Cd) pada ikan bandeng (Channos channos) di pertambakan kecamatan Pangkajene, dapat disimpulkan bahwa kadar logam berat kadmium (Cd) pada organ ginjal sebanyak 0,1071 ppm, pada organ hati sebanyak 0,1003 ppm, pada organ usus sebanyak $0,0665 \mathrm{ppm}$ dan pada otot sebanyak 0,0451 ppm.

\section{DAFTAR PUSTAKA}

Ahmad, Fasmi. Tingkat Pencemaran Logam Berat Dalam Air Laut dan Sedimen Di Perairan Pulau Muna, Kabaena, dan Buton Sulawesi Tenggara. Makara, Sains, Vol. 13 No. 2, November 2009: 117-124.

Budiyono dan Sutrisno. Pengaruh Pencemaran Kadmium Pada Air Sumur Untuk Minum Dan Memasak Terhadap Kesehatan Wanita Di Desa Bambe Kecamatan Driyerejo,Gresik. J Kesehat Lingkung Indones Vol.3 No.1 Oktober 2004: 61-65. 
Connel, D.W. dan G. J.Miller. Kimia dan Ekotoksikologi Pencemar. Penerjemah Yanti Koestoer dan Sahati. Jakarta: Universitas Indonesia Press, 2006.

Darmono. Lingkungan Hidup dan Pencemaran. Jakarta : Universitas Indonesia, 2001

Dampak Terhadap Manusia Akibat Tercemar Oleh Logam Berat Cadmium (Cd). http://mukono.blog.unair.ac.id/2009/09/09/efek-gas- terhadap - kesehatanlingkungan.html (Diakses 10 Oktober 2009).

Kandungan Gizi Bandeng. http ://food.fania.asia/ (Diakses 07 Oktober 2009)

Lestari dan Edward. Dampak Pencemaran Logam Berat Terhadap Kualitas Air Laut dan Sumberdaya Perikanan (Studi Kasus Kematian Massal Ikan-ikan di Teluk Jakarta). MAKARA, SAINS, VOL. 8, NO. 2, AGUSTUS 2004: 52-58.

Martaningtyas, Bahaya Cemaran Logam Berat. http://www.Pikiran rakyat.com/cetak/0704/29/cakrawala/lainnya 08. Htm 2007, (Diakses 01 Juli 2010).

Mursyidin, H. Dindin. Menanggulangi Pencemaran Logam Berat. Yayasan Cakrawala Hijau Indonesia. http://www.ychi.org/phixelthemes.com. 2006, (Diakses 1 Juli 2010)

Nursanti. Analisis Kandungan Logam Krom $(\mathrm{Cr})$ dan ammonium di Perairan Pantai Losari dan PT. KIMA Palopo. Makassar. Jurusan Kimia Universitas Hasanuddin, 2004.

Palar, H. Pencemaran dan Toksikologi Logam Berat. Jakarta: Rineka Cipta, 2008.

Prahasta, Arief dan Hasanawi Masturi. Agribisnis Bandeng. Bandung: CV Pustaka Grafika, 2008.

Rini. D. S. Mangrove Jenis Api-Api (Avecinia marina) Alternatif Pengendalian Pencemaran Logam Berat Pesisir. http://www.tetranet.or.id/tulisandetil.php?id=1300 (Diakses 03 Juli 2010)

Wibowo, "Awas Mainan Anak Anda Beracun" Kesehatan Media Indonesia. http://bataviase.co.id/node/130665 (Diakses 29 Juni 2010).

Widowati, Wahyu, A.Sastiono, dan R. Jusuf R. Efek Toksik Logam. Bandung: Andi Yogyakarta, 2008. 